Mature B-Hücreli Lösemiden Kaynaklanan Serebral Sinovenöz Trombozis ve Multipl Kranial Palsi

\title{
Cerebral Sinovenous Thrombosis and Multiple Cranial Palsies due to Mature
}

\section{B-Cell Leukemia}

Hüseyin Tan ${ }^{1}$, Arzu Tatar ${ }^{2}$, Mustafa Büyükavc1 ${ }^{3}$, Zuhal Keskin Yıldırım ${ }^{3}$ Özgür Yörük ${ }^{2}$, Hayri Oğul $^{4}$

${ }^{1}$ Atatürk Üniversitesi Tip Fakültesi, Pediatrik Nöroloji Bilim Dalı, Erzurum, Türkiye ${ }^{2}$ Atatürk Üniversitesi Tıp Fakültesi, Kulak Burun Boğaz Anabilim Dalı, Erzurum, Türkiye ${ }^{3}$ Atatürk Üniversitesi Tıp Fakültesi, Pediatrik Hematoloji ve Onkoloji Bilim Dalı, Erzurum, Türkiye ${ }^{4}$ Atatürk Üniversitesi Tıp Fakültesi, Radyoloji Anabilim Dalı, Erzurum, Türkiye

\section{$\ddot{O} Z$ :}

Akut lenfoblastik lösemi çocukluk çağının en sık hematolojik malignensisidir. Sık semptomlar, inatçı ateş, ilerleyici solukluk, kanama, kilo kaybı, kemik ve eklem ağrılarıdır. Biz, serebral sinovenöz trombozisi ve çoklu kranial palsisi olan akut lenfoblastik lösemili bir çocuk rapor ettik. Sonuç olarak, ayakta tedavi edilen her hastanın nörolojik muayenesinin dikkatli yapılmasını tavsiye ediyoruz. $\mathrm{Bu}$ yaklaşım kuşkusuz ciddi hastalıkların sebep olduğu ağır nörolojik bulguları ortaya çıkaracaktır.

Anahtar Kelimeler: Akut lemfoblastik lösemi, serebral sinovenöz trombozis, multipl kranial palsi

\section{SUMMARY:}

Acute lymphoblastic leukemia is the most common hematological malignancy in childhood. Common presenting symptoms are persistent fever, progressive pallor, bleeding, weight loss, bone pains and joint symptoms. We report a child with acute lymphoblastic leukemia who presented multiple cranial palsies and cerebral sinovenous thrombosis. As a result, we advise a careful neurological examination for every outpatient. This approach will undoubtedly reveal severe neurological findings due to serious diseases.

Keywords: Acute lymphoblastic leukemia, cerebral sinovenous thrombosis, multiple cranial palsies 


\section{Introduction}

Acute leukemia is the most common hematological malignancy in childhood. Acute lymphoblastic leukemia (ALL) accounts for $75 \%$ of the acute leukemias in children. Common presenting symptoms are persistent fever, progressive pallor, bleeding, weight loss, bone pains and joint symptoms. Typical findings include pallor, lymphadenopathy, petechiae, purpurae, bony tenderness, and hepatosplenomegaly. Extramedullary involvements such as the central nervous system (CNS), testes, kidneys, etc. may sometimes be found in absence of organomegaly $(1,2)$. However, clinical presentation of ALL as cerebral sinovenous thrombosis (CVST) is rare. To our best knowledge, such association has not been reported in any case with mature B cell ALL. Therefore, we describe a boy presenting with CVST, who was subsequently diagnosed as mature B cell ALL.

\section{Case Report}

A 5-year-old boy was presented with malaise, anorexia, diplopia, headache, and vomiting for two weeks. He had a history of normal neurologic development. There was no history of drug administration, or these symptoms proceeding in trauma. His past history revealed that he applied to a local hospital with the same complaints and that he was diagnosed as upper respiratory tract infection. He had been started oral amoxicilline one week before being admitted to our clinic. As his condition did not improve, even the vomiting became stronger, he was referred to the department of pediatric neurology.

On examination, his body temperature was $36.6{ }^{\circ} \mathrm{C}$, the blood pressure was $100 / 60 \mathrm{mmHg}$, the pulse was $85 / \mathrm{min}$, and the respiratory rate was $24 / \mathrm{min}$. His weight was $18 \mathrm{~kg}$ (3-10 percentile) and height was $112 \mathrm{~cm}$ (3-10 percentile). He was cachectic and had only submandibular microlymphadenopathies. Examination of the nervous system showed the trochlear, abducens and hypoglossal palsy in the right side and diplopia. The rest of neurological examination was unremarkable, especially, his fundus and pupil sizes. Otoscopic examination showed acute otitis media bilaterally.

Hematological findings were as follows: hemoglobin $12.2 \mathrm{~g} / \mathrm{dL}$, white blood cell count $13 \times 10^{9} / \mathrm{L}$ (60\% lymphocytes, $15 \%$ monocytes, $25 \%$ neutrophils), platelets $345 \times 10^{9} / \mathrm{L}$, and reticulocyte ratio $1 \%$. Blood smear showed no abnormality.

Urinalysis, liver and renal function tests did not show any abnormality. The sedimentation rate was 24 $\mathrm{mm} / \mathrm{h}$ and C-reactive protein was negative. Routine biochemical tests, particularly uric acid level, were normal. Lactate dehydrogenase was $700 \mathrm{IU} / \mathrm{L}$. To evaluate our patient for venous thrombophilia, he underwent the following laboratory investigations: cholesterol, triglycerides, homocystein, lipoprotein (a), fibrinogen, protein C, protein S, antithrombin, prothrombin 20210, factor V Leiden, homozygosity for the thermolabile variant of the methylene tetrahydrofolate reductase gene 
(tMTHFR), factor VIII, factor XII, anticardiolipin IgG and lupus anticoagulant. They were all within normal limits. The computed tomography of the brain showed a hyperdense lesion on the right transverse sinus. Magnetic resonance imaging and venography revealed the findings compatible with the thrombosis in the right sigmoid and transverse sinuses and the proximal internal jugular vein (Figure 1 and 2). We initially thought that the patient had cerebral sinus vein thrombosis due to acute otitis media and started enoxaparine $(1 \mathrm{mg} / \mathrm{kg} / \mathrm{dose}$, twice a day) and cephtriaxone $(100 \mathrm{mg} / \mathrm{kg} / \mathrm{d}$, bid).
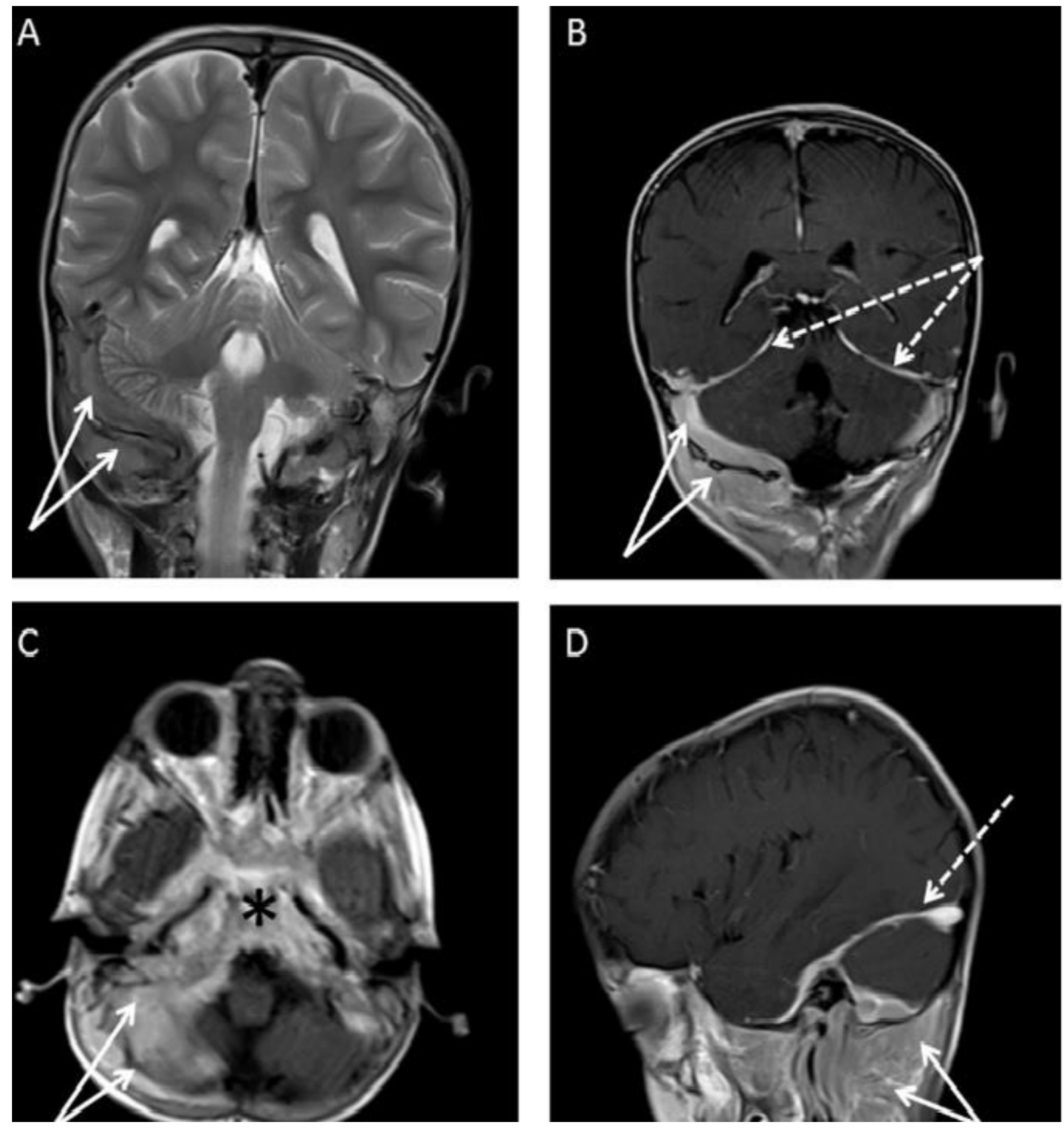

Figure 1: T2 weighted (A) magnetic resonance image shows extra and intracranial calvarial lesion (arrows) nearly isointense to gray matter. Coronal (B), axial (C), and sagittal (D) postcontrast T1weighted magnetic resonance imaging scans reveal marked enhancement of the lesion (arrows) and the dura (dotted arrows). The lesion also extends the basis of the cranium (asterisk). 

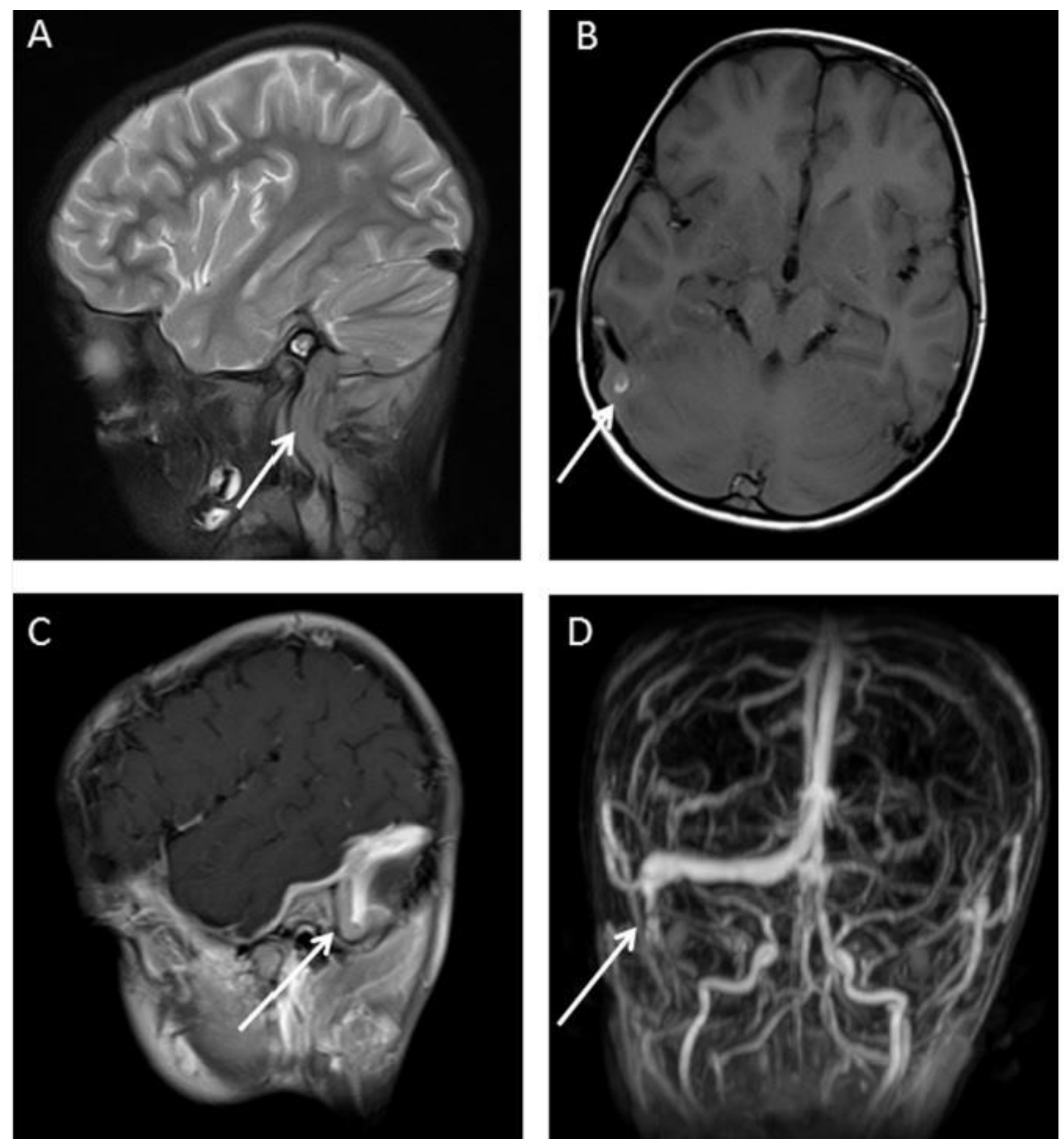

Figure 2: Coronal T2 (A) and axial T1 (B) weighted magnetic resonance imaging scans reval a thrombus (arrows) in the right sigmoid sinus. Post-contrast sagittal T1 weighted magnetic resonance imaging (C) reveal shows a nonenhanced thrombus (arrow) surrounded by enhanced sinus. Postcontrast magnetic resonance venography (D) image reveals non-visualisation (arrow) of the distal of the right sigmoid sinus.

We noticed the bilateral cervical lymph node enlargement during antibiotic treatment. An excisional lymph node biopsy was performed under general anesthesia, and histopathological examination showed a high-grade B cell lymphoma. Simultaneous bone marrow aspiration smear demonstrated $60 \%$ L3 type lymphoblast. Our case, finally, was diagnosed as a mature B-cell leukemia by the way of morphological and immunophenotypical assessments. In light of the extensive CNS and bone marrow involvement, chemotherapy was commenced with prednisolone, cyclophosphamide, vincristine, 
doxorubicin, methotrexate, cytarabine and etoposide. The patient's neurological status started to improve clinically 1 week after commencement of chemotherapy. He made good neurological recovery and after 2 months he was fully mobile without any neurological deficits. The cranial MRI performed at sixth month of therapy showed chronic period of thrombus.

\section{Discussion}

CVST is recognized in pediatric practice. At the present time, improvements in imaging and increased awareness among clinicians led to more frequent recognition of CVST in children. The general incidence of CVST is $<1$ per 100,000 children per year (3). The etiology of CSVT in children is usually multifactorial. A predisposing factor may be determined in up to 95\% of the cases with CSVT. These predisposing factors are fever, infection (especially otitis media and mastoiditis), dehydration, anemia, congenital heart disease, central venous line placement, renal diseases, metabolic conditions (homocystinuria), prothrombotic disorders, autoimmune disorders, some drugs (L-asparaginase), and malignancy (usually leukemia, lymphoma and brain tumors) (3). Also, CVST is an uncommon but a well-known complication associated with treatment for leukemia, most commonly observed if asparaginase is used in combination with other chemotherapeutic agents $(2,4)$. Contrary to this, our case presented with CVST.

Children with ALL are often presented with signs and symptoms that reflect bone marrow infiltration and/or extramedullary disease. An important extramedullary involvement is neurological involvement. The neurological involvement may appear as posterior reversible encephalopathy syndrome (5), sixth nerve palsy (6), hypoglossal nerve palsy (7), Guillain-Barré syndrome (8), facial paralysis (9), increasing intracranial pressure (10), cerebral sinovenous thrombosis (11), and oculomotor nerve palsy (12) but all of them are uncommon. Our patient was an interesting case of ALL who was presented as CVST and who raised concern about multiple cranial palsies. The mechanism of the multiple cranial palsies may be the seeding of the leptomeninges by neoplastic cells. In the practice of general pediatrics, therefore, it is very important to make a detailed neurological examination.

ALL is a disseminated and curable hematological cancer in childhood. The classification of ALL is done with respect to characteristics of the malignant cells in the bone marrow. They are the morphology, phenotypic characteristics, and cytogenetic and molecular genetic features. Morphological evaluation alone usually is adequate to establish a diagnosis, but the other studies are essential for disease classification. The immune-phenotypes of ALL are pro- $\mathrm{B}, \mathrm{CD}^{-}$precursor- $\mathrm{B}, \mathrm{CD}^{+}$ precursor-B, mature B-cell (Burkitt leukemia or L3 subtype) and T-cell. The L3 type, also known as Burkitt leukemia, has the most important distinguishing morphological feature (2).

When the leukemic blasts replace the bone marrow in ALL, patients are generally presented with signs of bone marrow failure, including anemia, thrombocytopenia, and neutropenia. Fever is common at presentation. Other common clinical manifestations include fatigue, pallor, petechiae, and bleeding. In 
addition, leukemic spread may manifest as lymphadenopathy and hepatosplenomegaly (2). Our patient had none of these general symptoms which suggest leukemia on admission. However, the presenting symptoms and findings of ALL in some degree depend on its subtypes. For example, in patients with B-precursor ALL, bone pain, arthritis, and limping may be presenting symptoms $(2,13)$. Mature-B ALL may be associated with extramedullary masses in the abdomen or head and neck and central nervous system involvement. Once again, in patients with T-lineage ALL, respiratory distress and stridor secondary to a mediastinal mass may be a presenting symptom (14). Although symptoms of CNS involvement including headache, vomiting, lethargy, and nuchal rigidity are rarely confronted at initial diagnosis, they are more common in T-lineage and mature B cell ALL $(2,15)$. Susanna et al (16) in their study including 1038 children reported that all of the 20 thrombosis cases appeared within the first five months of the treatment of ALL. We detected CSVT before leukemia therapy and then he was diagnosed as B-cell leukemia by bone marrow aspiration analysis. Our case exhibited a severe vomiting without symptoms of increased intracranial pressure at the presentation. They engrossingly resolved in a day after surgically resection. The mechanism of the vomiting is unclear.

As a result, we consider that pediatricians may overlook neurologic findings in pediatric practice especially in crowded outpatient clinics. Therefore, we advise that they should make a careful neurological examination for every outpatient. Naturally, this will reveal severe neurological findings due to serious diseases, such as ALL which can imitate all manner of illness.

\section{References}

1. Marwaha RK, Kulkarni KP, Bansal D, Trehan A. Acute lymphoblastic leukemia masquerading as juvenile rheumatoid arthritis: Diagnostic pitfall and association with survival. Ann Hematol. 2010;89: 249-54.

2. Tubergen DG, Bleyer A, Ritchey AK. Acute lymphoblastic leukemia. In: Behrman RE, Kliegman RM, Arum AM, eds. Nelson textbook of pediatrics. Philadelphia:WB Saunders; 2011. p. 1732-9.

3. Dlamini N, Billinghurst L, Kirkham FJ. Cerebral venous sinüs (sinovenous) thrombosis in children. Neurosurg Clin N Am. 2010; 21:511-27.

4. Ross CS, Brown TM, Kotagal S, Rodriguez V. Cerebral venous sinus thrombosis in pediatric cancer patients: long-term neurological outcomes. J Pediatr Hematol Oncol. 2013; 35: 299302.

5. Panis B, Vlaar AM, van Well GT, Granzen B, Weber JW, Postma AA, et al. Posterior reversible encephalopathy syndrome in paediatric leukaemia. Eur J Paediatr Neurol. 2010;14: $539-45$.

6. O'Neill EC, Connell PP, Kadare S, Tormey PT. Acute sixth nerve palsy in a young man, beware of the 'red herring'. Ir J Med Sci. 2010;179:301-3. 
7. Kamii Y, Hashimoto M, Suzuki M, Sakimoto Y, Kawasaki K, Yoshioka M. A case of isolated hypoglossal nerve palsy with acute lymphoblastic leukemia. Rinsho Shinkeigaku. 2013;53: 243-6.

8. Aral YZ, Gursel T, Ozturk G, Serdaroglu A. Guillain-Barré syndrome in a child with acute lymphoblastic leukemia. Pediatr Hematol Oncol. 2001;18: 343-6.

9. Buyukavci M, Tan H, Akdag R. An alarming sign for serious diseases in children: bilateral facial paralysis. Pediatr Neurol. 2002;27: 312-3.

10. Kaplinsky C, Bielorai B, Keidan I. Intracranial pressure in pediatric patients with acute lymphoblastic leukemia. Pediatr Blood Cancer. 2009; 53:513

11. Mazzoleni S, Putti MC, Simioni P, Sainati L, Tormene D, Manara R, et al. Early cerebral sinovenous thrombosis in a child with acute lymphoblastic leukemia carrying the prothrombin G20210A variant: a case report and review of the literatüre. Blood Coagul Fibrinolysis. 2005;16: 43-9.

12. Bhatt VR, Naqi M, Bartaula R, Murukutla S, Misra S, Popalzai M, et al. $T$ cell acute lymphoblastic leukaemia presenting with sudden onset right oculomotor nerve palsy with normal neuroradiography and cerebrospinal fluid studies. BMJ Case Rep. 2012; 27:2012.

13. Ganesan P, Thulkar S, Gupta R, Bakhshi S. Childhood aleukemic leukemia with hypercalcemia and bone lesions mimicking metabolic bone disease. J Pediatr Endocrinol Metab. May 2009;22:463-7.

14. Pui CH, Robison LL, Look AT. Acute lymphoblastic leukaemia. Lancet. Mar 22 2008;371(9617):1030-43.

15. Boggs W. Neurologic Changes Occur Long After Pediatric Lymphoid Malignancy. Medscape Medical News. Available at http://www.medscape.com/viewarticle/810241.

16. Ranta S, Tuckuviene R, Makipernaa A, Albertsen BK, Frisk T, Tedgard U, et al. Cerebral sinus venous thrombosis in children with acute lymphoblastic leukaemia-a multicenter study from the Nordic Society of Paediatric Haematology and Oncology. Br J Haematol. 2015;168:547-52 